\title{
Pengaruh Pakan Berbeda pada Induk Terhadap Jumlah Larva Ikan Guppy (Poecilia reticulata)
}

\author{
Effect of Different Type Food on Parents towards Total Larvae Guppy (Poecilia reticulata) \\ Nelsiani To'bungan
}

Fakultas Teknobiologi

Universitas Atma Jaya Yogyakarta

E-mail:nelsitobungan@gmail.com,nelsiani_tobungan@mail.uajy.ac.id

\begin{abstract}
Guppy fish (Poecilia reticulata) is one type of ornamental fish that is quite popular, because, in addition to its variety, its maintenance and cultivation is also quite easy. The effectiveness of feeding on the growth of aquaculture fish has been widely studied. However, information regarding the effects of feeding differently on the number of larvae is still very rare. Therefore, it is necessary to do research related to the effect of natural feeding of mosquito larvae and artificial feeding (pellets) to the number of larvae of Guppy fish. The experimental design used in this study was Completely Randomized Design, with 2 treatments (mosquito larvae and artificial feed) with each replication. The research procedure included the adaptation stage, the maintenance phase and the data collection phase. Total larvae of Guppy fish fed by mosquito larvae from 3 replications were 115 heads, while 16 were fed with artificial feed (pellets). Hypothesis testing with One Way Anova showed different feedings on the mains did not produce a significantly different number of larvae. Temperature data obtained during the study, indicating that the temperature was in the range 26-27 $\mathrm{C}$, the $\mathrm{pH}$ was in the range 6-7. The oxygen content in water used for maintenance was still within a good range of $4.66-7.61 \mathrm{mg} /$ L.
\end{abstract}

Key words: Guppy, Food, Total Larvae

\begin{abstract}
Abstrak
Ikan Guppy (Poecilia reticulata) merupakan salah satu jenis ikan hias yang cukup diminati, selain karena jenisnya beragam, karena pemeliharaann dan budidayanya terbilang cukup mudah. Efektifitas pakan terhadap pertumbuhan ikan budidaya, telah banyak diteliti. Namun, informasi terkait pengaruh pemberian pakan berbeda terhadap jumlah larva masih sangat jarang. Oleh sebab itu peru dilakukan penelitian terkait pengaruh pakan alami jentik nyamuk dan pakan buatan (pelet) terhadap jumlah larva ikan Guppy. Rancangan percobaan yang digunakan dalam penelitian ini adalah Rancangan Acak Lengkap dengan 2 perlakuan (pakan jentik nyamuk dan pakan buatan) dengan masing-masing 3 ulangan. Prosedur penelitian meliputi tahap adaptasi, tahap pemeliharaan dan tahap pengumpulan data. Total larva ikan Guppy yang diberi pakan jentik nyamuk dari 3 ulangan adalah 115 ekor, sementara yang diberi pakan buatan (pelet) sebanyak 16 ekor. Uji hipotesis dengan One Way Anova menunjukkan pemberian pakan yang berbeda pada Induk tidak menghasilkan jumlah larva yang berbeda nyata. Data suhu yang diperoleh selama penelitian menunjukkan suhu ada pada kisaran 26$27^{\circ} \mathrm{C}, \mathrm{pH}$ ada pada kisaran 6-7. Kandungan oksigen pada air yang digunakan untuk pemelihaaraan masih ada dalam rentang yang baik yaitu pada kisaran 4,66-7,61mg/L.
\end{abstract}

Kata kunci: Guppy, Pakan, Jumlah Larva

Diterima: 16 Agustus 2017, disetujui: 20 September 2017

\section{Pendahuluan}

Ikan Guppy (Poecilia reticulata) merupakan salah satu jenis ikan hias yang cukup diminati, karena jenisnya beragam, dan pemeliharaan dan budidayanya yang terbilang cukup mudah. Ikan Guppy jantan seperti halnya ikan Cupang (Betta splendens), memiliki morfologi yang lebih menarik dibanding ikan 
betina. Ikan ini memiliki nilai komersial yang tinggi di pasar dalam dan luar negeri. Harga ikan guppy kualitas premium mencapai kisaran harga delapan ratus ribu rupiah per pasang. Data profil perikanan budidaya di Indonesia, menunjukkan pertumbuhan rata-rata per tahun $64,8 \%$ (Sarida dkk., 2011). Hal tersebut didukung permintaan ikan Guppy yang terus meningkat, sehingga peningkatan jumlah produksi juga harus lebih ditingkatkan.

Pakan merupakan salah satu faktor yang harus dikontrol dengan baik untuk memastikan ikan budidaya bertumbuh dengan optimal sesuai usia. Pakan-pakan yang digunakan dalam budidaya ada yang merupakan pakan alami dan pakan buatan. Pakan alami yang sering dipakai adalah jentik nyamuk, karena kandungan protein dan lemak yang tinggi serta mudah didapatkan. Penelitian yang telah dilakukan sebelumnya terkait dengan pakan yang berpengaruh terhadap pertumbuhan ikan, menunjukkan ikan yang diberi pakan alami jentik nyamuk memiliki ratarata pertumbuhan biomassa yang lebih tinggi dibanding dengan yang diberi pakan alami Moina sp (Agus dkk., 2010). Pakan buatan yang digunakan dalam bentuk pelet, juga harus disesuaikan dengan ukuran bukaan mulut ikan. Tidak hanya itu, kandungan nutrisi pakan juga harus tetap dikontrol sehingga pakan buatan yang dipakai menjamin ketersediaan dan kebutuhan nutrisi yang dibutuhkan ikan. Jumlah dan pemilihan jenis pakan sangat berpengaruh terhadap pertumbuhan ikan budidaya.

Pakan alami berupa jentik nyamuk merupakan salah satu jenis pakan yang menjadi pilihan bagi para pembudidaya ikan. Ikan menyukai pakan alami yang satu ini karena dapat bergerak sehingga mudah untuk terlihat. Kelebihan lain yang dimiliki oleh pakan ini adalah relatif mudah untuk dibudidayakan dengan cara menampung air dalam keadaan terbuka, menjadi tempat nyamuk untuk bertelur. Bagi sebagian besar masyarakat, keberadaan jentik nyamuk pada suatu tempat merupakan hal yang sangat dihindari. Hal tersebut terkait dengan, beberapa penyakit mematikan yang diperantarai oleh nyamuk. Pemanfaatan jentik nyamuk sebagai pakan alami sekaligus mencegah agar jentik nyamuk tersebut tidak menjadi nyamuk. Sehingga, pemberian pakan dengan jentik nyamuk akan memberi dampak positif menekan populasi nyamuk. Sehingga berbagai penyakit yang diperantarai oleh nyamuk dapat ditekan.

Di sisi lain, maraknya budidaya ikan hias juga turut disertai dengan berkembangnya pakan buatan dengan berbagai formulasi. Pakan buatan menjadi salah satu alternatif pakan yang banyak dipilih pembudidaya ikan hias karena mudah untuk diperoleh dan didukung pula dengan harga yang terjangkau. Jenis dan ukurannya juga lebih beragam sehingga mudah untuk menyesuaikan dengan bukaan mulut ikan. Dikalangan peternak ikan, pakan buatan dikenal dengan sebutan pellet (pelet). Peternak ikan dapat membuat pelet sendiri dengan memanfaatkan limbah pertanian sehingga dapat lebih meminimalkan biaya. Limbah yang biasa digunakan seperti bungkil kelapa sawit, bungkil kacang tanah dan limbah tepung jagung (Devani dan Basriati, 2015).

Efektifitas pakan terhadap pertumbuhan ikan budidaya telah banyak diteliti. Namun, informasi terkait pengaruh pemberian pakan berbeda terhadap jumlah larva masih sangat jarang dijumpai. Terlebih penelitian terkait pengaruh pakan pada jumlah larva ikan Guppy. Oleh sebab itu perlu dilakukan penelitian untuk memperoleh data dan informasi yang dapat digunakan sebagai acuan dalam budidaya ikan Guppy. Sehingga jumlah larva dapat ditingkatkan secara maksimal. Sehingga dapat memenuhi permintaan pasar yang makin hari makin meningkat. Dalam penelitian ini akan dibandingkan penggunaan pakan alami jentik nyamuk dan pakan buatan dalam bentuk pelet. Pelet yang akan digunakan adalah pelet yang mencantumkan persentase kandungan nutrisi dengan jelas.

\section{Metode Penelitian}

Rancangan percobaan yang digunakan dalam penelitian ini adalah Rancangan Acak Lengkap, dengan 2 perlakuan dengan masingmasing 3 ulangan. Perlakuan yang dilakukan adalah:

1. Pemberian pakan jentik nyamuk

2. Pemberian pakan buatan (Pelet) 

berikut:

Tahapan pelaksanaannya adalah sebagai

\section{Tahap Adaptasi}

Ikan Guppy yang akan digunakan sebagai sampel terlebih dahulu diadaptasikan dengan lingkungan penelitian dan pakan uji selama 1 minggu. Hal tersebut dilakukan agar ikan terbiasa dengan kondisi lingkungan penelitian dan pakan uji yang akan diberikan. Air yang digunakan sebagai media adalah air sumur yang diendapkan minimal 2 hari. Hal tersebut dilakukan untuk menjaga kondisi kesehatan benih ikan Cupang.

\section{Tahap Pemeliharaan}

Ikan Guppy kemudian dimasukkan ke dalam wadah pemeliharaan dengan kepadatan 5 ekor/wadah pemeliharaan. Pakan yang akan diberikan disesuaikan dengan perlakuan. Pemberian pakan akan dilakukan 3 kali sehari secara ad libitum. Pemberian pakan sesuai perlakuan dilakukan selama 1 bulan, sampai usia indukan 3 bulan. Kemudian, induk jantan dan betina dikawinkan, setelah itu pemberian pakan sesuai perlakuan dilanjutkan sampai induk melahirkan.

\section{Pengumpulan Data Jumlah Larva}

Ikan Guppy yang melahirkan, segera dipisahkan dengan larvanya. Larva dimasukkan ke dalam akuarium yang berbeda, kemudian dihitung jumlahnya. Data tambahan yang diukur dalam penelitian ini adalah data kualitas air berupa $\mathrm{pH}$, Suhu, dan oksigen terlarut (DO).

\section{Hasil dan Pembahasan}

Data jumlah larva dalam Tabel 1. diuji untuk mengetahui normalitas dan homogenitas data yang diperoleh, dengan $\alpha=0,05$. Berdasarkan uji Liliefors diketahui bahwa data terdistribusi normal dengan nilai signifikansi variable 0,123 dan 0,056 dan uji homogenitas dengan One Way Anova menunjukkan data homogen dengan signifikansi 0,165. Uji hipotesis dengan One Way Anova menunjukkan nilai $F$ hitung $>$ dari $F$ tabel. Nilai $F$ hitung 232,5 dan F tabel 7,709. Dengan demikian, diperoleh hasil bahwa pemberian pakan berbeda pada induk tidak berpengaruh berbeda terhadap jumlah larva ikan Guppy (Poecilia reticulata). Hal ini menunjukkan bahwa jumlah larva indukan Guppy dengan jenis pakan berbeda tidak berbeda nyata. Histogram jumlah larva ikan Guppy dengan pemberian pakan jentik nyamuk dan pelet disajikan dalam Gambar 1 .

Jumlah larva yang dihasilkan indukan dipengaruhi oleh kualitas telur yang dihasilkan oleh indukan. Kualitas telur berpengaruh terhadap jumlah larva yang akan bertahan sampai pada saat ditetaskan atau dilahirkan. Salah satu faktor yang mempengaruhi kualitas telur adalah pakan yang diperoleh oleh induk. Pakan yang kualitas dan kuantitasnya mencukupi akan berpeluang memberikan dampak yang positif terhadap peningkatan jumlah larva (Palacios dkk., 2001).

Meskipun berdasarkan hasil analisis data statistik menunjukkan pemberian pakan berbeda tidak memberikan pengaruh yang berbeda nyata terhadap jumlah larva, namun dapat dilihat dari Gambar 1. bahwa jumlah larva yang dihasilkan induk yang diberi pakan jentik nyamuk lebih banyak daripada yang diberi pakan pelet. Hal tersebut menunjukkan bahwa pakan jentik nyamuk baik digunakan untuk tujuan perbanyakan larva. Larva yang dihasilkan dari perlakuan pakan jentik nyamuk pada induk lebih banyak dipengaruhi oleh kandungan nutrisi yang cukup baik yang terdapat pada jentik nyamuk (Agus dkk., 2010).

Perbandingan kandungan nutrisi yang terdapat pada jentik nyamuk dan pelet yang digunakan dalam penelitian ini dapat dilihat pada Tabel 3.

Jika dilihat dari perbandingan kandungan nutrisi pada Tabel 3. diketahui bahwa jentik nyamuk memiliki kandungan lemak dan air yang lebih tinggi dari pelet. Sementara pelet memiliki kandungan protein yang jauh lebih besar dibanding pelet. Hal ini menunjukkan bahwa jumlah lemak yang banyak dibutuhkan untuk perkembangan telur dan larva. Indukan yang diberi pakan jentik nyamuk, cenderung lebih bersemangat untuk menghabiskan pakan tersebut dibanding dengan induk yang diberi pakan pelet. Hal ini disebabkan jentik nyamuk diberikan dalam keadaan hidup, sehingga pergerakan jentik nyamuk, lebih menarik perhatian induk untuk memakannya dibanding dengan pakan 
pelet yang hanya mengapung (Anggraeni dan Abdulgani, 2013).

Data lain yang diperoleh selain data biomassa adalah data $\mathrm{pH}$, suhu dan $\mathrm{DO}$ air. Data-data tersebut disajikan dalam Tabel 2.

Data suhu yang diperoleh selama penelitian, menunjukkan bahwa suhu ada pada kisaran $26-27^{\circ} \mathrm{C}$. Sementara $\mathrm{pH}$ ada pada kisaran 6-7. Suhu dan $\mathrm{pH}$ tersebut masuk dalam suhu dan $\mathrm{pH}$ yang dapat ditoleransi oleh ikan Guppy. Untuk toleransi pH ikan Guppy memiliki kisaran toleransi yang cukup luas yaitu pada kisaran 311, sementara untuk suhu batas toleransinya adalah pada $25,6-33,4^{\circ} \mathrm{C}$ (Sukmara, 2008). Kandungan oksigen pada air yang digunakan untuk pemelihaaraan masih ada dalam rentang yang baik yaitu pada kisaran 4,66-7,61 ppm, karena DO air 0,3-1 $\mathrm{mg} / \mathrm{L}$ dapat menyebabkan kematian (Effendie, 2003).

Tabel 1. Data Jumlah Larva ikan Guppy

\begin{tabular}{|c|c|c|c|}
\hline Perlakuan & Ulangan & Jumlah Larva Tiap Perlakuan (n) & $\Sigma$ Larva \\
\hline \multirow{3}{*}{ Pakan Jentik Nyamuk } & 1 & 10 & 115 \\
\hline & 2 & 68 & \\
\hline & 3 & 37 & \\
\hline \multirow[t]{3}{*}{ Pakan Buatan (pelet) } & 1 & 3 & 16 \\
\hline & 2 & 4 & \\
\hline & 3 & 9 & \\
\hline
\end{tabular}

Tabel 2. Hasil Pengukuran Kualitas Air Selama Penelitian

\begin{tabular}{cll}
\hline No & Parameter & Hasil \\
\hline 1 & $\mathrm{pH}$ & $6-7$ \\
2 & Suhu & $26-27^{\circ} \mathrm{C}$ \\
3 & Do & $4,66-7,61 \mathrm{mg} / \mathrm{l}$ \\
\hline
\end{tabular}

Tabel 3. Perbandingan Kandungan Nutrisi Jentik Nyamuk dan Pelet (pf500)

\begin{tabular}{lll}
\hline Kandungan Nutrisi Pakan & Jentik Nyamuk (\%) & Pelet $(\boldsymbol{p f 5 0 0 ) ( \% )}$ \\
\hline Protein & 15,58 & 39 \\
Lemak & 7,81 & 5 \\
Serat & 3,46 & 4 \\
Air & 68,18 & $10 \%$ \\
Abu & 1,4 & 14 \\
\hline
\end{tabular}

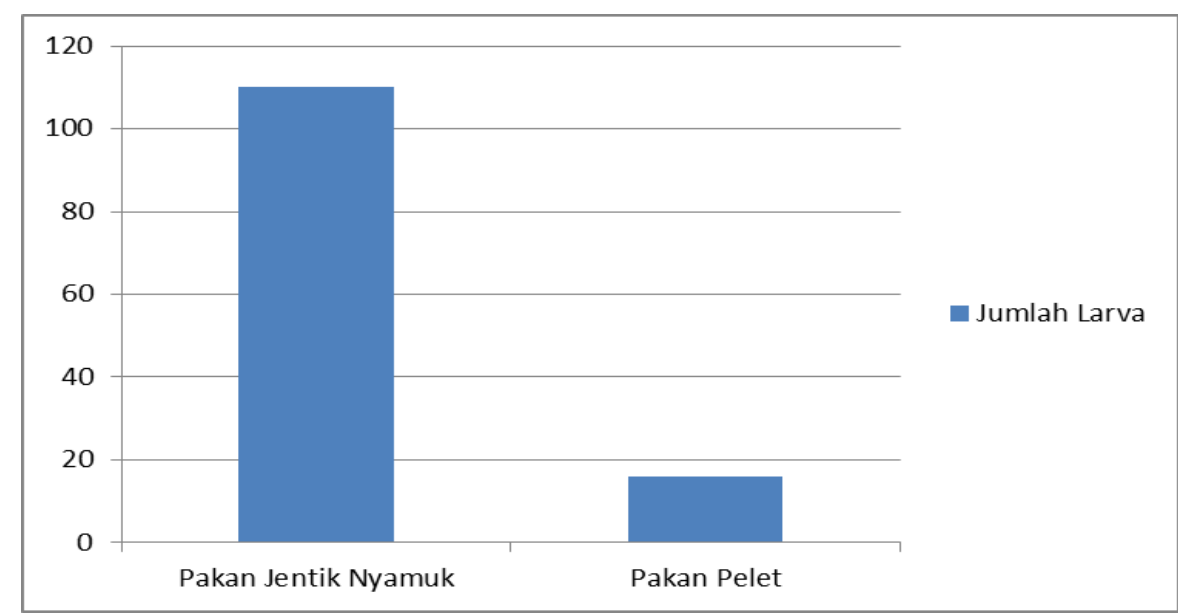

Gambar 3. Histogram Jumlah Larva Ikan Guppy dengan Perlakuan Pakan Jentik Nyamuk dan Pelet. 


\section{Simpulan}

Larva ikan Guppy yang berasal dari induk yang diberi pakan jentik nyamuk dan pelet menunjukkan perbedaan jumlah. Indukan yang diberi pakan jentik nyamuk menghasilkan larva dengan jumlah yang lebih banyak dengan total larva untuk 3 ulangan adalah 115. Sementara Indukan yang diberi pakan pelet total larva 16 untuk 3 ulangan.

\section{Daftar Pustaka}

Agus, M., Yusufi M.T., dan Nafi B. 2010. Pengaruh Perbedaan Jenis pakan Alami Daphnia, Jentik Nyamuk dan Cacing Sutera Terhadap Pertumbuhan Ikan Cupang Hias (Betta Splendens). PENA Akuatika, 2 (1): 21-29.

Anggraeni, N.M., dan Abdulgani, N. 2013. Pengaruh Pemberian Pakan Alami dan Pakan Buatan Terhadap Pertumbuhan Ikan Betutu. Jurnal Sains dan Seni Pomits, 2 (1): 2337-3520.

Devani, V. dan Basriati, S. 2015. Optimasi Kandungan Nutrisi Pakan Ikan Buatan dengan Menggunakan Multi Objective (Goal) Programming Model. Jurnal Sains, Teknologi dan Industri, 12 (2): 255-261.
Effendie, H. 2003. Telaah Kualitas Air Bagi Pengelolaan Sumber Daya dan Lingkungan Perairan. Kanisius. Yogyakarta.

Palacios, E., Racotta, I.S., Heras, H., Marty, Y., Moal, J., dan Samain, J.F. 2001. Relation between Lipid and Fatty Acid Composition of Eggs and Carval Survival in White Pacific Shrimp (Penaeus vannamei Boone, 1931).

Mutiara Sakti. 2015. Prima Feed. http://www.mataharisakti.com. Diakses pada April 2017

Sarida, M., Dwi, P.D. dan Marsewi, H.S.Y. 2011. Produksi Monoseks Guppy (Poecilia reticulata) Jantan dengan Perendaman Induk Bunting dan larva dalam Propolis Berbagai Aras Dosis. Zoo Indonesia, 20 (2): 1-10.

Sukmara. 2007. Sex Reversal pada Ikan Gapi (Poecilia reticulate Peters) Secara Perendaman Larva dalam Larutan Madu 5ml/l. Departemen Budidaya Perairan. Fakultas Perikanan dan Ilmu Kelautan, IPB. Bogor. 